UDC: [372.016:81'243]:373.3.011.3-051

DOI: https://doi.org/10.24195/2414-4665-2017-5-17

Maryna Vasylyk,

PhD (Candidate of Pedagogical Sciences), associate professor,

Department of Foreign Languages,

State Higher Educational Institution Vasyl Stefanyk

"Precarpathian National University"

57, Shevchenko Str., Ivano-Frankivsk, Ukraine,

Ivan Rusnak,

Doctor of Pedagogy, professor,

head of the Department of Foreign Languages,

Khmelnytskyi Humanitarian-Pedagogical Academy,

139, Proskurivskoho pidpillia Str., Khmelnytskyi, Ukraine

\title{
IMPROVEMENT OF FOREIGN LANGUAGE TRAINING OF FUTURE PRIMARY SCHOOL TEACHERS
}

The article focuses on the necessity of forming foreign language communicative competence of future primary school teachers as a condition of their successful professional activities in the period of active integration of Ukraine into the European and the world educational space. The expansion of international cooperation requires modern specialists' command of a foreign language as a tool which not only allows to navigate in the modern society fluently, but also to perform their professional functions efficiently, to expand their professional and cultural horizons in the process of attracting them to diverse sources of information. The necessity of learning a foreign language arises at primary school, and, consequently, there is a necessity of training pedagogues, capable of forming junior schoolchildren's foreign communicative competence. The main emphasis in teaching a foreign language should be placed on mastering language and speech competences; it is necessary to develop future specialist's ability to communicate in a foreign language in real professional pedagogical situations in order to encourage the subjects of the educational process. The modern innovative teaching technologies (information-communicational (computer), game, training) form the basis of teaching a foreign language for specific purposes. The game technologies arise special interest of students, for example a business game reproduces the behaviour and work of individual employees: teachers, principals, head teachers, class teachers. These technologies bring them closer to their future professional duties, provide the opportunity to prepare for the teaching practice at school, to acquire the necessary abilities and skills of communication with the primary school pupils. The use of common traditional methods of active learning provides the achievement of educational goal of learning a foreign language. They are verbal - conversation, dialogue: visual - interactive demonstration, corporate - working in small groups, carousel; collective-group -analysis of situations, brainstorming, problem solving: situation-simulation games; discussion - discussion, debates; research-method of projects.

Keywords: primary school teacher, foreign language training, communicative competence, innovative educational technologies, business game, educational-speech activity, speech situations, language-speech competence, active teaching methods, phonetics, lexical and grammatical competences.

\section{Introduction}

The formation of future primary school teachers' foreign language communicative competence as a necessary condition of their successful professional activities in the period of active integration of Ukraine into the European and the world educational space is one of the most difficult problems of modern higher educational institutions. First of all it is explained by the new vision of the functions of a foreign language in people's life and its status in the society, which results in corresponding changes in the programs for foreign language teaching. A foreign language becomes the means of intercultural communication and command of it leads to mutual understanding in any multicultural and multilingual space. The most important task for the university graduates is not only practical mastery of a foreign language, but also acquisition of those social and cultural communicative and behavioural skills that will help them in the future. We should mention that the expansion of international cooperation requires modern specialists' command of a foreign language as a tool, which not only allows to navigate in the modern society, but also to perform their professional functions efficiently, to expand their professional and cultural horizons in the process making them familiar with diverse sources of information. Hence the necessity of learning a foreign language arises at primary school, and, consequently, there is a necessity in training teachers, capable of forming junior schoolchildren's foreign-language communicative competence. It is the appropriate period for the formation of key communicative competence, which is manifested in the ability to use the language (all kinds of speech activity) in the process of communication, understanding the world, solving existential problems. That is why the search for the effective 
means of the formation of future primary school teachers' communicative competence is one of the most important tasks of national pedagogical science and first of all it concerns linguistic didactics.

Taking into account the urgency of the issue studied, a number of both Ukrainian and foreign scientists have been investigating its various aspects (for example, O. Bida, L. Koval, O. Komar, S. Martynenko, O. Mytnyk, L. Khomych, L. Khorunzha). Innovative approaches in teaching linguistic and linguistic-didactic disciplines have been studied by M. Vashulenko, N. Holub, S. Karaman, L. Matsko, M. Pentyliuk, O. Pometun, etc. Methods of forming foreign language communicative competence have been examined by domestic and foreign scientistsmethodologists (I. Berman, V. Bukhbinder, V. Korostyliov, S. Shatilov, V. Hnatkevych, Yu. Passov, H. Kitaihorodskyi, B. Labinska, O. Tarnopolskyi, E. Miroshnychenko, I. Batsenko, V. Borshchovetska, R. Ellis, J. Nation, N. Schmitt W. Widdowson, etc.). However, some aspects of the issue of the formation of this quality in future primary school teachers still remain understudied.

The paper aims to analyze the peculiarities of the formation of foreign language communicative competence of the future primary school teachers and to distinguish the most effective ones.

\section{Discussion}

The modern Ukrainian educational system, according to the fundamental documents of the Council of Europe, among which there are the following: "GeneralEuropean Recommendations on Language Education: Learning, Teaching, Assessment", "European Language Portfolio", "Bilingually education: Key Strategic Tasks", "Bringing Language Exams in Accordance with European Recommendations and Requirements to European Examinations" and the like, is focused on providing the appropriate level of foreign language teaching, formation of foreign language communicative competence of the future specialists. In particular, the recommendations of the Council of Europe on language education are reflected in the State standard of general secondary education and foreign language Program for secondary schools; common European levels of proficiency in the foreign language are taken into account in the Typical Programs in the first foreign language for universities / institutes that prepare teachers and translators (2004); in the Program on the English language for professional communication (2005), worked out together with the British Council, etc. The tendency of turning from the concept of "knowledge" to the concept of "competence" is peculiar for the modern paradigm of education, because it deals with the educational aspect of foreign language training. Formal transfer of knowledge as a centered model of education (as distinct from the formation of skills of its practical use in various spheres of activity) does not satisfy the real needs of the society. This tendency has led to the searching for new approaches to teaching foreign languages in particular, for specific purposes. It is necessary to consider that its study for the Slavs (Ukrainians, Poles, Bulgarians, Russians, Serbs, Slovaks, etc.) requires first of all specific adjustment of the articulating apparatus, the study of grammar, quite different from the Slavic, etc. That is why we need effective technologies / approaches that take into account all these peculiarities, and which could be used in the countries of Eastern and Western Europe.

In this context, we consider that the main emphasis in teaching foreign language should be placed on the mastering of language and speech competences. It is necessary to develop students' ability to communicate in a foreign language in real situations of professional pedagogical activity.

That is why the teaching process should be based on modern innovative teaching technologies. ICT are one of the leading means of achieving competitive position; that is why the consideration of their role and importance in the educational market is quite relevant. We should pay attention to the fact that there are also gaming technologies (game, business game), computer technologies (computerization of education), dialog technologies related to the creation of communicative environment (pedagogical interaction), trainings, interactive technologies. Business games reproduce the behaviour and work of individual employees - in our case teachers, principals, class teachers), which bring them closer to their future professional activities, provide the opportunity to prepare for the teaching practice at school, to acquire the necessary abilities and skills of communication with the primary school pupils. Students enjoy the role of a young teacher, playing fragments of lessons in primary school, preparing for their implementation in advance, according to clearly defined tasks of a course teacher. They enthusiastically compose linguistic stories about the parts of speech for primary school pupils, acquire communicative skills and abilities for their future work in the field of teaching [2].

The organization of active professionally focused learning and speech activity of students is affected by the situational and role-based learning using simulated classroom communicative situations with the aim of motivating learners for using necessary language material.

Thus, in order to obtain the knowledge and mastery of methodological skills, necessary for the formation of primary school pupils' phonetic, lexical and grammar competences, future teachers should learn to:

- make a methodical analysis of phonetic, lexical, and grammatical phenomena of the English language;

- analyze the techniques and ways of presenting phonetic, lexical and grammar material and the exercises recommended for its mastering;

- use effective methods and techniques for the formation of phonetic, lexical, grammatical competencies of pupils;

- plan and conduct fragments of lessons aimed at teaching phonetic, lexical and grammatical material in English.

Profound learning of theoretical conceptions is facilitated by discussing the main concepts of foreign-language 
phonetic, lexical and grammatical competences, stages, and means of their formation at practical lessons, as well as performing the following tasks:

1. To write down grammatical / lexical material which pupils have to learn both receptively and productively from the primary school curriculum for different classes, that is, to recognize and understand it when listening and reading, as well as to use in the process of speaking and writing.

2. To choose one example of each kind of phonetic exercises.

3. To choose one example of each type of grammar exercises.

4. To choose one example of each type of lexical exercises [1, p. 52].

Besides, the students are offered the following tasks for individual homework:

1. Make the independent search, using the Internet resources, of the exercises for the formation of phonetic, lexical, grammatical competences and offer primary school pupils to perform them.

2. Prepare and demonstrate verbal and non-verbal tools for teaching phonetic, lexical and grammatical material.

3. Get acquainted with the fragments of lessons for learning phonetic, lexical and grammatical material at primary school (Fragments are taken from the source: Bihych, O. B. (2006). Theory and practice of methodical competence formation of teachers of foreign language of primary schools : training manual. Kyiv: Lenvit). Based on the proposed fragments form your own fragments of the lesson [1, p. 52].

As an example for the future primary school teachers the fragment of the lesson how to teach the primary school pupils to pronounce the sound $[\mathrm{w}]$ is offered.

I. Acquaintance with the new sound [w].

Purposes: to arouse pupils' need and interest in the studied material, to familiarize pupils with the new sound [w].

Teacher (T.): do you know the tale by J. R. Kipling, «The Elephant»? Have you seen the cartoon? And what is its main feature? He was curious. His best friends were the words What, Why, When, How, Where, Who. Method 1 - Demonstration of the sound $[w]$ in speaking.

T: The elephant liked the poem about these words. Listen to its first verse.

Six Serving Men

I keep six honest serving men.

They taught me all I knew.

Their names are What and Why and When And How and

Where and Who.

Then the author should ask pupils to try to translate the poem into their native language.

Why did the curious elephant like these words? In the English language they begin the so-called special questions. [w].

Method 2 - Explanation of articulation of the sound

T: The English sound [w] is very unusual. No other language of the world has it. The London wind will teach you how to pronounce the English sound [w]. To pronounce it, you should first round the lips, and then abruptly separate them [w-w-w] - so sometimes blows the London wind.

Method 3 - Comparison with the sounds of the native language.

T: The Ukrainian language has a sound similar to the English sound [w]. It is labio-dental sound [v]. Why is it called so? Because when we pronounce it, the lower lip touches the upper teeth.

Method 4 - Articulatory gymnastics.

T: Look at your mirrors: round your lips as if you are going to blow out the candle, and then abruptly relax them. Again protrude the lips forward as far as possible and then rapidly relax them.

II. Automation of pupils' actions with the new sound.

Objectives:

- to teach pupils to comprehend the sound [w],

- to teach pupils to pronounce the sound [w] in isolation, in words, phrases, sentences.

Reception (exercises aimed at the development of phonemic awareness): Exercise 1 - recognition.

Objective: to teach pupils to recognize the sound [w] among other sounds.

$\mathrm{T}$ : Listen to the words and rise transcription symbol of the sound [w] when you hear the word with this sound: twenty, wine, vine, vent, we, went, well, van, will, veil.

Exercise 2 - differentiation.

Objective: to teach pupils to distinguish the sounds [w] and [v].

T: Listen to the pairs of words with the sounds [w] and $[\mathrm{v}]$, and determine the same (put sign + ) or different (put sign -). Their first sounds: 1 . wine - vine, 2 . west wet, 3. veal - veil, 4. warm - vent, 5 . when - why, 6 . vet white, 7 . we - watch, 8 . wheel -vest, 9. wine - while, 10. van - what.

Exercise 3 - identification.

Objective: to teach children to recognize the sound $[\mathrm{w}]$ as known with certain characteristics.

T: Listen to tape-recorded words with the sounds $\mid \mathrm{w}]$ and [v]; during the pause after each word rise the appropriate transcription sign - [w] or [v]: wine, grapes, vent, went, until, a week, a veil, kit, van, wheel.

The tasks offered to the pupils after reviewing the fragments of lessons for independent work provide the diversity of training, enhancing their productivity and deepening their linguistic-speech competence. As an example, we suggest making fragments of the lesson aimed at teaching pronunciation and intonation to primary school pupils: according to your taste, choose one of the existing textbooks and manuals for primary school. Motivate the pupils' interest to the acquisition of new phonetic material. Identify educational techniques for each stage of 
teaching pronunciation and intonation. Select didactic material for phonetic exercises out of your methodical portfolio prepared during the individual work. Define the educational potential of the phonetic material. In writing, present the prepared fragments of the lesson, being ready to conduct them.

Experience shows that in a speech situation the approbation of patterns and models of learning and speech activity takes place, verbal behavior of students is formed, their attention is mobilized, imagination is developed, the process of learning becomes more interesting, that is, the ideal concept of possible and appropriate norm of activity for achieving the goal is designed and implemented. These general characteristics of the situation as a communication exercise in full concern the job-relevant training, as through the prism of modeling the process of communication in communicative situations, it is possible to recreate the multi-faceted content of the future professional activity of students.

The use of the following common traditional methods of active teaching provides the achievement of the main educational goal of learning a foreign language: verbal (conversation, dialogue) visual (interactive demonstration), corporate (working in small groups, carousel);

\section{REFERENCES}

1. Labinska, B. I., Gumeniuk, O. Ya., Tumak, O. M. (2015). Praktykum z metodyky navchannia anhliiskoi movy v pochatkovii shkoli: navch. Posibnyk [Workshop on methods of teaching English in primary school: textbook]. Chernivtsi, Chernivtsi National University [in Ukrainian].

2. Romaniuk, S. Z. (2017). Innovatsiini pidkhody do navchannia linhvistychnykh dystsyplin maibutnikh uchyteliv pochatkovoi shkoly [Innovative Approaches to

\section{ЛІТЕРАТУРА}

1. Практикум з методики навчання англійської мови в початковій школі: навч. Посібник / уклад.: Б. І. Лабінська, О. Я. Гоменюк, О. М. Тумак. - Чернівці, Чернівецький національний університет, 2015. - 184 с. team work (analysis of situations, brainstorming, problem solving, role-playing); discussion (debates); research (project-based learning).

\section{Conclusions}

Therefore, studying the scientific and methodological literature and practical experience of the formation of future primary school teachers' foreign language communicative competence gives the grounds to assert that the efficiency of this process can be improved with the help of the following factors:

- humanization of the educational process, which involves the disclosure of students' personal potentials;

- professionally-oriented communicative focus of the process of learning a language, which is implemented by means of using a set of teaching methods (communicative, audio-lingual, audiovisual); forms (business game, creation of practice-oriented situations, conversation, round table discussion);

- activation of cognitive activity in the field of implementation of the provisions of the student-centered approach

- enhancing learning motivation through the use of not only common methods of teaching, but also of computer and Internet technologies.

Teaching Linguistic Disciplines of the Future Primary School Teachers]. Naukovi zapysky Rivnenskoho derzhavnoho humanitarnoho universytetu: Onovlennia zmistu, form ta metodiv navchannia $i$ vykhovannia $v$ zakladakh osvity - Scientific notes of Rivne State Humanitarian University: Updating of the content, forms and methods of teaching and upbringing in educational institutions, (Vol.15 (58), pp. 140-144. Rivne [in Ukrainian].

2. Романюк С. 3. Інноваційні підходи до навчання лінгвістичних дисциплін майбутніх учителів початкової школи / С. 3. Романюк // Наукові записки Рівненського державного гуманітарного університету: Оновлення змісту, форм та методів навчання і виховання в закладах освіти. - Вип.15 (58). - Ревне, 2017. - С.140-144.

Марина Степанівна Василик кандидат педагогічних наук, дочент кафедри іноземних мов, Прикарпатський національний університет імені Василя Стефаника, вул. Шевченка, 57, м. Івано Франківськ, Україна Іван Степанович Руснак, доктор педагогічних наук, професор, завідувач кафедри іноземних мов Хмельницька гуманітарно-педагогічна академія, вул. Проскурівського підпілля, 139, м. Хмельницький, Украӥна

\section{УДОСКОНАЛЕННЯ ІНШОМОВНОЇ ПІДГОТОВКИ \\ МАЙБУТНІХ УЧИТЕЛІВ ПОЧАТКОВОЇ ШКОЛИ}

У статті акцентовано увагу на необхідності формування іншомовної комунікативної компетентності майбутнього вчителя початкової школи як необхідної умови його успішної професійної діяльності. Зазначено, що 
розширення міжнародного співробітництва вимагає від сучасного фахівця володіння іноземною мовою на принципово новому рівні - як інструментом, який дозволяє не тільки вільно орієнтуватися в сучасному суспільстві, але і якісно виконувати свої професійні функції, розширювати свій професійний і культурний світогляд у процесі залучення до різноманітних джерел інформації. Звідси цілком закономірно випливає необхідність оволодіння іноземною мовою вже в початковій школі, а, відповідно, і потреба в підготовці педагогічних кадрів, спроможних забезпечити формування іноземної комунікативної компетентності молодшого школяра. За допомогою використання сучасних методів науково-педагогічних досліджень (структурний метод, змістовий аналіз, абстрагування, класифікація та узагальнення даних, індуктивний та дедуктивний методи) доведено, що головний акцент у навчанні іноземної мови необхідно ставити на оволодіння мовно-мовленнєвими компетенціями, виробляти у майбутніх фахівців здатність спілкуватися іноземною мовою у реальних ситуаціях професійнопедагогічної діяльності, спонукати до неї суб'єктів навчально-виховного процесу. Встановлено, що в основу навчання іноземної мови професійного спрямування покладено сучасні інноваційні технології навчання (інформаційно-комунікаційні (комп’ютерні), ігрові, тренінгові). Обгрунтовано, що особливий інтерес у студентів викликають ігрові технології, а саме ділова гра (відтворюється поведінка і робота конкретних працівників: учителя, директора, завуча, класного керівника.), які наближують їх до майбутньої професійної діяльності, дають можливість краще підготуватися до проходження педагогічної практики в школі, набути необхідних умінь i навичок спілкування 3 молодшими школярами. 3'ясовано, що досягнення навчальної мети вивчення іноземної мови забезпечує використання таких найпоширеніших традиційних методів активного навчання, як: словесні бесіда, діалог: наочні - інтерактивна демонстрація, корпоративні - робота в малих групах, карусель; колективно-групові - «аналіз ситуацій», «мозковий штурм», вирішення проблем: ситуативні - імітаційні ігри; дискусійні - дискусія, дебати; дослідницькі - метод проектів.

Ключові слова: учитель початкової школи, іншомовна підготовка, комунікативна компетентність, інноваційні технології навчання, ділова гра, навчально-мовленнєва діяльність, мовленнєві ситуації, мовно-мовленнєва компетентність, активні методи навчання, фонетична, лексична і граматична компетентність.

Submitted on April, 19, 2017 